\title{
Considerations about ocular neoplasia of dogs and cats
}

\author{
Considerações sobre neoplasias oculares em cães e em gatos
}

\section{Luciano Fernandes da Conceição ${ }^{\mathrm{I}}$ Alexandre Pinto Ribeiro ${ }^{\mathrm{I}}$ Dunia Yisela Trujillo Piso ${ }^{\mathrm{I}}$ José Luiz Laus ${ }^{\mathrm{II}}$}

\section{- REVIEW -}

\section{ABSTRACT}

Primary and secondary neoplasia of dogs and cats may assume several different forms. Clinical signs are varied, and are manifest in accordance with the diseased tissue. The present article aims to review clinical and pathophysiologic aspects of frequent neoplasms that affect by the eye and the adnexal ocular structures of dogs and cats.

Key words: dog, cat, eye, adnexa, neoplasms.

\section{RESUMO}

As neoplasias oculares primárias, assim como as secundárias em cães e gatos podem se apresentar sob diversas formas. Os sinais clínicos são variados e se manifestam de acordo com o tecido acometido. Visa-se com o presente artigo realizar uma breve revisão dos aspectos clínicos $e$ fisiopatológicos mais significativos das neoplasias que acometem olhos e os anexos oculares de cães e gatos.

Palavras-chave: cão, gato, olhos, anexos, cão, gato, neoplasias.

\section{INTRODUCTION}

Adnexa, ocular tunics and other structures of the eye can be affected by primary and secondary neoplasia. The condition may vary considerably depending on location and nature of the neoplastic abnormality developed by each type of cell.
Inflammation and secondary glaucoma may arise from neoplasms, which are considered vision-threatening and may cause loss of the eye (WILLIS \& WILKIE, 2001).

Primary neoplasms

Eyelid

Eyelid tumors are commonly found in dogs, and are presented as raised cutaneous masses that may have originated from epithelial, mesenchymal or melanogenic cells (WILLIS \& WILKIE, 2001). Ocular papillomas are usually encountered in young dogs, and its etiology may be related to papillomavirus infection (MILLER \& DUBIELZIG, 2005). Generally, they have a wart-like appearance, are well-circumscribed, superficial, and do not infiltrate deeply into the surrounding tissues (MILLER \& DUBIELZIG, 2005). In cats, cutaneous papillomas rarely occur; when they are diagnosed, they usually have a stalk-like appearance, and the skin around the lesion is alopecic (BERNAYS et al., 1999).

Sebaceous gland tumors, squamous cell papillomas and melanocytic tumors (Figure 1- A, B) are frequently found in the eyelids of dogs and tend to be benign; although their progressive growth can be associated of self trauma and chronic irritation.

'Programa de Pós-graduação em Cirurgia Veterinária, Faculdade de Ciências Agrárias e Veterinárias (FCAV), Universidade Estadual Paulista (Unesp), Jaboticabal, SP, Brasil.

"Departamento de Clínica e Cirurgia Veterinária, FCAV, Unesp. Via de Acesso Professor Paulo Donato Castellane S/N, 14884-900, Jaboticabal, SP, Brasil. E-mail: jllaus@fcav.unesp.br. Autor para correspondência 


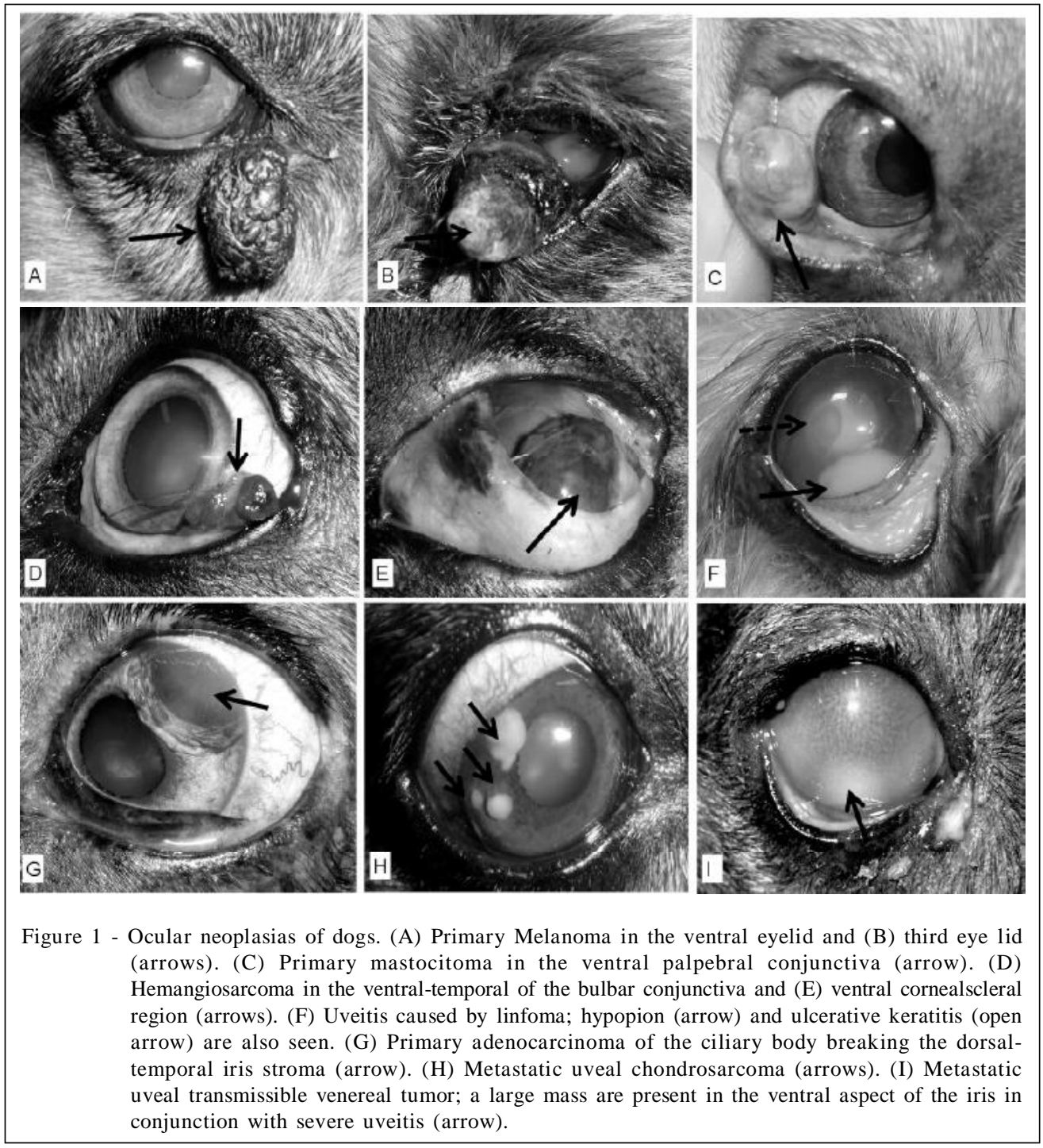

Sebaceous gland tumors, generally arise from tarsal glands. Among these, sebaceous adenomas, sebaceous epitheliomas, and sebaceous adenocarcinomas, are commonly encountered; size and pigmentation of these masses vary considerably. Other tumors that may affect the eyelids of dogs are basal cell epitheliomas, basal cell carcinomas, fibromas, fibrosarcomas, neurofibromas, and neurofibrosarcomas.

Histiocytic cutaneous tumors may affect the eyelids as well, notably in the dog. They are presented as smooth and alopecic masses, display a pink-like appearance and are stationary. It is the most common neoplasia seen in young dogs and surgical excision is indicated, as they can be locally invasive; however, spontaneous resolution often occurs (WILLIS \& WILKIE, 2001).

Primary eyelid neoplasias develop with less frequency in cats. Squamous cell carcinoma (SCC) has been reported as the most common eyelid tumor in animals with 10 years of age or older (GILGER et al., 1992). The condition presents as a proliferative pink to white mass, which normally is ulcerated. White cats are predisposed and the medial canthal eyelid is primarily affected (DITERS \& WALSH, 1984). In both dogs and cats, solar radiation exposure, lack of melanin and chronic irritative diseases are conditions that predispose to the development of this tumor (KREHBIEL \& LANGHAM, 1975; BARRIE et al., 1982; BERNAYS et al., 1999).

SCCs are usually superficial, but the actinic plaque may invade deeper tissues (MILLER \& DUBIELZIG, 2005). Although it rarely occurs, there are reports of SCC that metastasized to distant organs (MILLER \& DUBIELZIG, 2005).

Hemangiosarcomas are tumors originated from vascular endothelium, and in the eye, they are 
generally manifested by the bulbar conjunctiva. A few case series of these neoplasms are reported in cats and dogs (MULTARI et al., 2002; LIAPIS \& GENOVESE, 2004; HARTLEY et al., 2006).

Basal cell tumors, such as mast cell tumors and fibrosarcomas have been reported in cats with a higher prevalence when compared to dogs (DITERS \& WALSH, 1984). Evaluation of fine-needle aspirated material may address both diagnose and prognosis. Surgical resection is warranted when abundant vascularization or superficial irritation are seen (WILLIS \& WILKIE, 2001). Dogs may have one third of the palpebral fissure excised; larger lesions may require more complicated surgical reconstruction techniques. Laser photocoagulation or local chemotherapy, associated with systemic treatment, may be curative is cases in which the size of the neoplastic tissue precludes surgery (WILLIS \& WILKIE, 2001).

Conjunctiva, sclera, cornea and limbus

Squamous cell carcinoma

Chronic irritations of different origins are considerate to be cause. Keratoconjunctivitis sicca, keratoconjunctivitis secondary to enophtalmia, solar irradiation, and traumatic lesions are also predisposing factors (MILLER \& DUBIELZIG, 2005; MONTIANIFERREIRA et al., 2008). The condition has a low metastatic potential (MILLER \& DUBIELZIG, 2005).

Papilloma

Corneal papillomas are slow-growing typically benign in origin. Normally, they are associated with canine papillomavirus infection and rarely occur in cats (BERNAYS et al., 1999). Ocular papillomas may spontaneously regress; nonetheless, masses that compromise areas amenable to recurrent irritation require surgery (WILLIS \& WILKIE, 2001).

\section{Conjunctival melanomas}

Conjunctival melanomas generally affect the nictitating membrane, the eyelids, and the bulbar and/ or palpebral conjunctiva. Lesions appear as dark raised solid masses. Lymphatic, orbital, and pulmonary metastases are feasible to occur. Correlation between mitotic rate and tumor recurrence or metastasis could not be proved in one study (PATNAIK \& MOONEY, 1988).

Complete surgical removal is warranted in early diagnosed cases. In addition, cryotherapy may reduce the recurrence rate. Preoperative evaluation requires a detailed abdominal and thoracic cavity investigation (COLLINS et al., 1993).
Limbal melanomas

Canine and feline limbal melanomas that affect dogs and cats present a benign biological behavior. They present as raised, well-circumscribed heavily pigmented masses that arise from scleral and subconjunctival connective tissue melanocytes (DONALDSON et al., 2006a). Most of them develop slowly adjacent to the superior aspect of the limbus. Exposure to solar radiation is considerate to be a risk factor (DONALDSON et al., 2006a). Affected dogs have, on average, 6.2 years of age (DONALDSON et al., 2006a), whereas cats are 8 years of age or older (MILLER \& DUBIELZIG, 2005). Gender or coat color predilections were not observed in dogs (DONALDSON et al., 2006a). However, a recent study showed that Labrador Retrievers are genetically predisposed (DONALDSON et al., 2006a). Conjunctival melanomas, epibulbar extension from canine anterior uveal melanomas, staphylomas and scleral coloboma must be differentiated from limbal melanomas (MILLER \& DUBIELZIG, 2005).

Therapy must be considered in cases where the tumor has compromised intraocular structures or if growth is rapid. Sclerectomy, with or without lamellar keratectomy must be performed and the defect covered with a graft placement. Most of these modalities are often curative (ANDRADE et al., 2004; DONALDSON et al., 2006).

Strontium- 90 beta irradiation, cryosurgery or laser photocoagulation may be employed as adjuncts to surgery (MILLER \& DUBIELZIG, 2005; DONALDSON et al., 2006b). Local recurrence is reported to occur in $30 \%$ of patients.

Conjunctiva e nictitating membrane Hemangioma and hemangiosarcoma

Hemangiomas and hemangiosarcomas are tumors that originate from the vascular endothelium bed (MILLER \& DUBIELZIG, 2005). Despite their high incidence, a definitive diagnosis is not always performed (PIRIE et al., 2006). In a large case series that examined 70 hemangiomas and 38 hemangiosarcomas of dogs, and 6 hemangiomas and 2 hemangiosarcomas of cats, revealed that average age upon presentation was 8.6 years in dogs, and 10.6 years in cats; there was no sex or breed predisposition for dogs, whereas domestic short hair cats where overrepresented (PIRIE et al., 2006).

In dogs, primary involvement occurred within nonpigmented epithelium along the leading edge of the nictitating membrane and temporal bulbar conjunctiva (Figure 1D, E) (PIRIE et al., 2006). PIRIE et al. (2006), found that the numbers of confirmed cases 
were significantly superior within breeds classes of increased outdoor activity dogs, which strongly suggest that ultraviolet light as a significant risk factor. Recent data showed that estrogen receptor-alfa may be involved in promoting the invasive behavior associated with hemangiosarcomas of $\operatorname{dogs}$ (CHANDLER et al., 2009). In dogs, it have been demonstrated that early surgical removal is nearly $100 \%$ curative for hemangiomas; recurrence, however, occur in 55\% of cases of hemangiosarcoma (PIRIE et al., 2006).

In cats, hemangiomas and hemangiosarcomas accounted for $0.17 \%$ and $0.06 \%$, respectively, of total feline submissions to a pathology laboratory in Wisconsin (U.S.A.). The third eyelid was the most common anatomical site of involvement (PIRIE, 2006; DUBIELZIG, 2002). Although tumor re-growth of any excised tumor was not observed, one should considerate that recurrence is possible, once a low number of cats were enrolled in one study $(\mathrm{n}=8)$ (PIRIE, 2006; DUBIELZIG, 2002).

\section{Mast cell tumors}

Mast cell tumors may involve the conjunctiva (Figure 1C) and the nictitating membrane of dogs. Variable swelling originated from mast cell degranulation and histamine release may be seen in the affected tissues. In the current veterinary literature, metastasis have not been reported (HALLSTROM, 1970; JOHNSON et al., 1988; BARSOTTI et al., 2007). Nevertheless, such result should be interpretated cautiously, once long term follow up was available in only one case (BARSOTTI et al., 2007).

BARSOTTI et al. (2007), reported good results by managing a 4 year-old Labrador with prednisone and vinblastine as an adjuvant treatment to surgery. The chemotherapy drug is recommended when safety margins were not achieved by surgical resection (BARSOTTI et al., 2007).

\section{Adenocarcinoma e fibrosarcoma}

Adenocarcinomas have been described in the lacrimal gland of the third eyelid of elderly dogs. En bloc extirpation of the whole nictitating membrane is the most appropriated procedure in such cases, once recurrence commonly occurs. Fibrosacormas and adenocarcinomas have been reported to invade the nictitating membrane of cats. These neoplasms are malignant and have been associated with metastatic disease (KOMAROMY et al., 1997).

Conjuntival impression citology and biopsy are recommended as a minimum data base for tumor diagnosis (BOLZAN et al., 2005; MILLER \& DUBIELZIG 2005). Adetailed diagnostic work up, aiming to investigate distant metastatic sites is fully recommended, principally in proliferative lesions affecting the nictitating membrane of cats (WILLIS \& WILKIE, 2001).

Regional lymph node fine needleaspiration, orbital ultrasonography, skull and thoracic radiographs, computed tomography and magnetic resonance imaging may be required for precisely localize and predict malignancy of masses. Such techniques are indicated in cases of SCC, mast cell tumors, third eyelid adenocarcinomas, and in conjunctival melanomas (MILLER \& DUBIELZIG, 2005).

\section{Uveal tumors}

Melanoma

In dogs, benign melanocytomas account for approximately $80 \%$ of uveal tumors of melanocytic origin, with malignant melanomas accounting for $20 \%$. Melanomas represent the most frequent form of primary intraocular neoplasia. They may originate from the anterior uvea, ciliary body, and less commonly, from the choroid (ESSON et al., 2007). The confirmed incidence of metastasis for primary canine uveal melanoma is low, with numbers approaching $4 \%$ having been reported (ESSON et al., 2007). Metastatization generally occurs hematogenously by conjunctival or periorbital vessels, by direct diffusion through scleral and corneal tissues, as well as by the optic nerve head (MILLER \& DUBIELZIG, 2005). Growing rate of tumors from melanocityc origin is variable (MILLER \& DUBIELZIG, 2005).

Grossly, their aspect is highly variable, but normally they are raised pigmented masses with a bulkylike appearance (MILLER \& DUBIELZIG 2005). Benign melanomas, generally appears heavily pigmented than malignant ones. However, an amelanotic mass secondary to a nailbed melanoma has been reported in one dog (ESSON et al., 2007).

Histologically, melanomas are very similar to limbic melanocytomas. There is no breed or sex predilection; nevertheless, Retriviers and other similar breeds in which the amount of cutaneous pigmentation in higher, may be more predisposed (MILLER \& DUBIELZIG, 2005; ESSON et al., 2007). Even in benign cases, uveal melanomas are invasive, and usually induce the eye to develop glaucoma, due to free-floating neoplastic cells or spaceoccuping masses, which compromise or blockage the aqueous outflow (ESSON et al., 2007).

Melanomas affecting the choroid may delay or even preclude the diagnosis until retinal detachment, pre-retinal fibrovascular membranes or vitreal hemorrhages are noticed. Extension of a choroidal 
melanoma to sclera, optic nerve of orbit may warrant more cautious prognosis (MILLER \& DUBIELZIG, 2005). Iridectomy of small masses or enucleation of painful eyes are the therapeutical options. In addition, Nd: YAG or diode photocoagulation are considered to be safe and are feasible methods to address treatment in isolate and pigmentated small masses of dogs and cats (COLLINS \& MOORE, 1999).

Diffuse iris melanoma is the most common primary intraocular neoplasia in cats (WILLIS \& WILKIE, 2001; MILLER \& DUBIELZIG, 2005). They originate in the anterior aspect of the iris, creating multifocal areas of pigmentation. Despite the highly invasiveness index of this tumor to the iris and ciliary body, they rarely affect the choroid. Neoplastic cells may infiltrate to the adjacent sclera, along the scleral venous plexus (MILLER \& DUBIELZIG, 2005). Common clinical signs are iris hyperpigmentation, decreased or absent pupilary light reflexes and secondary glaucoma. Differently from dogs, metastasis are uncommon. However, metastatic disease was confirmed in $62.5 \%$ of 16 cats in one study (WILLIS \& WILKIE, 2001). Regional lymphatic nodules, liver, and lungs are the principle sites for metastatasis formation. Location of neoplastic cells, extent of ocular involvement, and mitotic index appear to predict the evolution of this condition (WILLIS \& WILKIE, 2001).

An atypical primary ocular melanoma has been described in cats. It originates multifocally from various portions of the uvea, other than the iris and progresses to destroy all portions of the eye. Unidentified small masses that arise in the posterior segment, close to the ora serrata, are difficulty be visualized by direct biomicroscopy, increasing their metastatic potential (WILLIS \& WILKIE, 2001).

In cats, the therapy of choice to manage uveal melanoma is controversial. One study investigating the survival in cats that underwent enucleation owing to diffuse melanoma showed that tumor invasion to the ciliary body or iris stroma, or with secondary glaucoma due to tumor ingrowth, decrease lifetime in comparison with age-matched healthy cats (KALISHMAN et al., 1998).

\section{Adenomas and adenocarcinomas}

Although extremely rare in humans, iridociliary adenoma and iridociliary adenocarcinoma are common primary tumors of the canine globe (Figure $1 \mathrm{G})$. Masses display different patterns of pigmentation and invasiveness, are solid or pedunculated (KLOSTERMAN et al., 2006), and usually arise from the nonpigmentated epithelium of the ciliary body (WILLIS \& WILKIE, 2001). Golden Retriever and
Retriever Labradors have been reported as predisposed breeds(WILLIS \& WILKIE, 2001). Immunohistochemistry showed that citokeratin AE1 and citokeratin AE3 were more consistently expressed in adenocarcinomas and less frequently in the adenomas, whereas none of the tumor types were positive for citokeratin 7 . In regard to aggressiveness, an inverse expression pattern was seen to citokeratin 20 (decreased in adenocarcinomas and increased in adenomas) and telomerase reverse transcriptase (increased in adenocarcinomas and decreased in adenomas) (KLOSTERMAN et al., 2006).

\section{Post-traumatic sarcomas}

Post-traumatic sarcomas are primary malignant neoplasms which develop in cats following traumatic injury or in chronic inflamed eyes. Most of the patients present history of globe perforation, in addition to lens capsule rupture, which is normally identified on histology. Usually, most cats do not show signs of pain or irritation but are blind owing to a phthisical eye (MILLER \& DUBIELZIG, 2005). Masses tend to infiltrate in a circumferential manner, invading the optic disc, and extension of optic chiasm was the cause of blindness in the contralateral eye of one cat. These tumors, often within the same eye, exhibit a spectrum of changes ranging from granulation tissue to fibrosarcoma, osteosarcoma, and anaplastic spindle cell sarcoma (WILLIS \& WILKIE, 2001). An algorithm for differential diagnostic of intraocular sarcoma has been purposed (GRAHN et al., 2006). Initial positivity for periodic acid Schiff histochemical staining, followed by vimentin and pancytokeratin negative labeling suggests further investigation. Negative labeling of the tumor for neurospecific enolase and the presence of lens capsule rupture on histology confirms the diagnose (GRAHN et al., 2006).

The time between the traumatic event and the initial lesions may vary from less than one year to more than 10 years. In cases where the eye is severely inflamed or painful, enucleation may be considerate (WOOGet al., 1983; DUBIELZIG, 1984).

Orbital tumors

Dogs and cats rarely develop retrobulbar neoplasms. Despite their low occurrence rate (around $4 \%$ of all cancers), more than $90 \%$ of these tumors are malignant (MILLER \& DUBIELZIG, 2005). The histological pattern is variable, and they can be of primary origin, arising from surrounding orbital tissues, or secondary to other neoformations within the eye or at distant sites (ATTALI-SOUSSAY et al., 2001; MILLER\& DUBIELZIG 2005).

Clinically, the most common manifestation is exophthalmos, leading them to be misdiagnosed as 
glaucoma (MILLER \& DUBIELZIG, 2005; ATTALISOUSSAY et al., 2001).

Considering the orbital neoplasms that affect cats, SCC is the most frequent one, followed by other types of carcinoma, lymphoma, melanoma, and other variants of sarcomas. Less frequently, hemangioma, condroma, meningioma, plasmacytoma and osteosarcoma have been described (MILLER \& DUBIELZIG, 2005). Recently, one case of retrobulbar melanoma without ocular involvement has been reported in a Burmese cat (LORIMIER, 2006). In most patients, tumors have a primary origin. However, secondary retrobulbar tumors, arising from primary melanomas, primary conjunctival, sinus or oral carcinomas, or from systemic lymphoma, may occur (MILLER \& DUBIELZIG 2005; LORIMIER, 2006).

In dogs, orbital neoplasia reported with a higher frequency are osteosarcomas, soft tissue sarcomas, carcinomas, mast cell tumors, meningiomas and lobe adenomas (WILLIS \& WILKIE, 2001; MILLER \& DUBIELZIG, 2005; LORIMIER, 2006; ATTALISOUSSAY et al., 2001).

Exenteration is typically recommended as palliative therapy for primary orbital neoplasms, particularly in cases where the associated eye is blind or painful owing to the effects of exposure. Orbitotomy for salvage of a visual eye may be considered when diagnostic imaging and cytologic analysis of an orbital mass suggests the presence of a potentially resectable benign primary orbital neoplasm. (WILLIS \& WILKIE, 2001; MATTON \& NYLAND, 2002; MILLER \& DUBIELZIG 2005).

\section{Secondary neoplasms}

Lymphoma is the most common secondary intraocular neoplasm in dogs and cats, with ophthalmic disease being present in $37 \%$ of dogs in one study (WILLIS \& WILKIE, 2001; GONZALES et al, 2005; MILLER \& DUBIELZIG, 2005). Generally, they reach the uveal tract leading to moderate to severe uveitis and intraocular hemorrhage or hypopion (Figure 1F); however, infiltration of the cornea is also possible. (WILLIS \& WILKIE, 2001; OSSOINING, 2004; MILLER \& DUBIELZIG, 2005). Additionally, exophthalmia resulting from resulting from orbital invasion of the tumor and vision loss due to optic nerve and nervous central system may be seen, as well as posterior segment abnormalities, such as retinal hemorrhages and retinal detachment. Lifespan of dogs with intraocular lymphomas seem to be lower when compared to counterparts that did not develop ocular disease.
Adenocarcinomas may also arise from distant metastatic sites (Figure 1D) such as the lungs mammary tissue, thyroid gland, liver, pancreas, and uterus (WILLIS \& WILKIE, 2001). Choroidal metastasis of angioinvasive pulmonary carcinoma resulting in ischemic chorioretinophy has been described in four cats (CASSOTIS et al., 1999).

Appropriate chemo therapy may lead to remission. Topical specific medication may be required to address intraocular inflammation (MILLER \& DUBIELZIG, 2005). Tumors with aggressive behavior invading the eye may end up with the recommendation of enucleation. Such procedure may provide the clinician valuable diagnostic information (WILLIS \& WILKIE, 2001; MILLER \& DUBIELZIG, 2005).

In rare occasions canine transmissible venereal tumor (TVT) may metastasize to the eye and associate structures (Figure 1I) (WILLIS \& WILKIE, 2001; OSSOINING 2004; MILLER\& DUBIELZIG 2005). In cases where ocular masses are found, and concurrent detectable genital or skin focus reassembling TVT is not apparent, immunohistochemistry positivity for vimentin, and a negative expression for S-100 protein, HMB45, and cytokeratin may aid in the differentiation from other round cell tumors (PEREIRA et al., 2000).

Other secondary intraocular neoplasms to be considered include chondrossarcoma (Figure 1H), hemangiosarcoma, cutaneous and oral melanoma, malignant histiocytosis, seminoma, transitional cell carcinoma of the urinary bladder, as well as the urethra, neurogenic sarcoma, osteosarcoma, rhabdomyosarcoma, anaplastic fibrosarcoma, pheochromocytoma, and adenocarcinoma of mammary gland, thyroid gland, parotid salivary gland, and of nasal, renal, and pancreatic origin (RODRIGUES Jr. et al., 2009).

\section{CONCLUSION}

Ocular neoplasia may be primary or secondary; primary ones have a low metastatic potential to distant sites. Full diagnostic work up by means of diagnostic imaging techniques, cytology and biopsy must be considerate in all suspected cases. Regardless of its anatomical location, the excision of the entire neoplastic tissue is often curative. More elaborate blepharopasty techniques are usually required when larger masses involve the eyelids. Likewise, orbitotomiy and surgical removal of small masses (even intraocularly) are feasible procedures of treatment for experienced surgeons. Molecular biology and immunohistochemistry are valuable diagnostic tools to demonstrate specific cellular markers and viral antigens when conventional histopathology is unclear. 


\section{ACKNOWLEDGEMENTS}

The authors would like to thank Conselho Nacional de Pesquisa (CNPq) and Fundação de Amparo à Pesquisa do Estado de São Paulo (FAPESP) for the scholarships provided.

\section{REFERENCES}

ANDRADE, A.L. et al. Repair of lamellar scleral lesions in dogs with preserved equine renal capsule - Short report. Arquivos Brasileiros de Oftalmologia, v.67, p.169-171, 2004. Available from: <http://www.scielo.br/pdf/abo/v67n1/ a31v67n1.pdf. $>$ Accessed: Feb. 15, 2010. doi: 10.1590/S000427492004000100031.

ATTALI-SOUSSAY, K. et al. Retrobulbar tumors in dogs and cats: 25 cases. Veterinary Ophthalmology, v.4, n.1, p.1927, 2001. Available from: <http://www3.interscience.wiley.com/ cgi-bin/fulltext/118999646/PDFSTART >. Accessed: Feb. 18, 2010. doi: 10.1046/j.1463-5224.2001.00123.x

BARSOTTI, G. et al. Primary conjunctival mast cell tumor in a Labrador Retriever. Veterinary ophthalmology, v.10, n.1, p.6064, 2007. Available from: <http://www3.interscience.wiley.com/ cgibin/fulltext/118507719/PDFSTART>. Accessed: Feb. 15, 2010. doi: $10.1111 /$ j.1463-5224.2007.00502.x.

BERNAYS, M.E. et al. Primary corneal papilloma and squamous cell carcinoma associated with pigmentary keratitis in four dogs. Journal of the American Veterinary Medical Association, v.214, n.2, p.215-217, 1999. Available from: <http://www.ncbi.nlm.nih.gov/pubmed/9926011>. Accessed: Feb. 15, 2010.

BARRIE, K.P. et al. Eyelid squamous cell carcinoma in four dogs. Journal of the American Animal Hospital Association, v.18, p.123-127, 1982.

BOLZAN, A.A. et al. Conjunctival impression cytology in dogs. Veterinary Ophthalmology, v.8, n.6, p.401-405,2005. Available from: <http://www3.interscience.wiley.com/cgi-bin/ fulltext/118669463/PDFSTART>. Accessed: Feb. 18, 2010. doi: 10.1111/j.1463-5224.2005.00414.x.

CASSOTIS, N.B. et al. Angioinvasive pulmonary carcinoma with posterior segment metastatic in four cats. Veterinary Ophthalmology, v.2, n.2, p.125-131, 1999. Available from: <http://www3.interscience.wiley.com/cgi-bin/fulltext/ 119091082/PDFSTART>. Accessed: Feb. 18, 2010. doi: 10.1046/j.1463-5224.1999.00068.x.

CHANDLER, H.L. et al. Immunohistochemical analysis of ocular hemangiomas and hemangiosarcomas in dogs. Veterinary Ophthalmology, v.12, n.2, p.83-90, 2009. Available from: <http://www3.interscience.wiley.com/cgi-bin/fulltext/ 122232202/PDFSTART >. Accessed: Feb. 18, 2010. doi: 10.1111/j.1463-5224.2008.00684.x.

COLLINS, B.K; MOORE, C.P. Diseases and surgery of the canine anterior uvea. In: GELATT, K.N. Veterinary ophthalmology. 3.ed. Philadelphia: Lippincott, Williams \& Wilkins, 1999. Chap.22. p.755-795.

COLLINS, B.K. et al. Biological behavior and histologic characteristics of canine conjunctival melanoma. Progress in Veterinary and Comparative Ophthalmology, v.3, p.135-140, 1993.

DITERS, R.W.; WALSH, K.M. Feline basal tumors: a review of 124 cases. Veterinary Pathology, v.21, n.1, p.51-56, 1984.

DONALDSON, D. et al. Canine limbal melanoma: 30 cases (19922004). Part 1. Signalment, clinical and histological features and pedigree analysis. Veterinary Ophthalmology, v.9, n.2, p.115119, 2006. Available from: <http://www3.interscience.wiley.com/ cgi-bin/fulltext/118599181/PDFSTART>. Accessed: Feb. 18, 2010. doi: $10.1111 / \mathrm{j} .1463-5224.2006 .00448 . x$

DONALDSON, D. et al. Canine limbal melanoma: 30 cases (1992-2004). Part 2. Treatment with lamellar resection and adjunctive strontium-90beta plesiotherapy-efficacy and morbidity. Veterinary Ophthalmology, v.9, n.3, p.179-185, 2006. Available from: <http://www3.interscience.wiley.com/ cgi-bin/fulltext/118599196/PDFSTART >. Accessed: Feb. 18, 2010. doi: 10.1111/j.1463-5224.2006.00468.x.

DUBIELZIG, R.R. Tumors of the eye. In: MEUTEN, D.J. Tumors in domestic animals. 4.ed. Ames, IW: Iowa State, 2002. Chap. 15, p.739-754.

DUBIELZIG, R.R. Ocular sarcoma following trauma in three cats. American Veterinary Medical Association, v. 184, n.5, p.578-581, 1984.

ESSON, D. et al. Suspected uveal metastasis of a nail bed melanoma in a dog. Veterinary Ophthalmology, v.10, n.4, p.262-266, 2007. Available from: <http://www3.interscience.wiley.com/cgibin/fulltext/118507749/PDFSTART>. Accessed: Feb. 8, 2010. doi: 10.1111/j.1463-5224.2007.00540.x.

GILGER, B.C. et al. Orbital neoplasms in cats: 21 cases (19741190). Journal of the American Veterinary Medical Association, v.201, n.7, p.1083-1086, 1992. Available from: <http://www.ncbi.nlm.nih.gov/pubmed/1429140>. Accessed: Feb. 18, 2010.

GONZALEZ, E.M. et al. Review of ocular ultrasonography. Veterinary Radiology and Ultrasound, v.42, n.6, p.485495, 2005. Available from: <http://www3.interscience.wiley.com/ cgi-bin/fulltext/118990294/PDFSTART >. Accessed: Feb. 18, 2010. doi: 10.1111/j.1740-8261.2001.tb00975.x.

GRAHN, B.H. et al. Classification of feline intraocular neoplasms based on morphology, histochemical staining, and immunohistochemical labeling. Veterinary Ophthalmology, v.9, n.6, p.395-405, 2006. Available from: <http:// www3.interscience.wiley.com/cgi-bin/fulltext/118599227/ PDFSTART >. Accessed: Feb. 18, 2010. doi 10.1111/j.14635224.2006.00479.x.

HALLSTROM, M. Mastocytoma in the third eyelid of a dog. Journal of Small Animal Practice, v.11, n.7, p.469-472, 1970.

HARTLEY, C. et al. Case report. Cutaneous haemangiosarcoma of the lower eyelid in an elderly white cat. Journal of Feline Medicine and Surgery, v.9, n.1, p.78-81, 2007. Available from: <http:// www.sciencedirect.com/science?_ob=ArticleURL\&_udi=B6WJC4KSSWK01\&_user $=10 \&$ _coverDate $=02 \% 2 \mathrm{~F} 28 \% 2 \mathrm{~F} 2007 \& \_$rdoc $=$ $1 \& \_\mathrm{fmt}=$ high \&_orig $=$ search\&_sort $=\mathrm{d} \& \_d o c a n c h o r=\& v i e w=c \& \_s e a$ rchStrId $=1421162266 \& \_$rerunOrigin $=$google $\& \_$acct $=C 000050221 \&$ 
_version $=1 \& \_u r l V e r s i o n=0 \& \_u s e r i d=10 \& m d 5=c 6 d 1255 \mathrm{a} 5 \mathrm{~d} 252 \mathrm{ba6d} 872 \mathrm{~b} 0 \mathrm{bd}$ 655984fd . Accessed: Feb. 18, 2010. doi 10.1016/j.jfms.2006.05.011.

JOHNSON, B.W. et al. Conjunctival mast cell tumor in two dogs. Journal of the American Animal HospitalAssociation, v.24, p.439-442, 1988.

KALISHMAN, J.B. et al. A matched observational study of survival in cats with enucleation due to diffuse iris melanoma. Veterinary Ophthalmology, v.1, n.1, p.25-29, 1998. Available from: <http://www3.interscience.wiley.com/cgi-bin/fulltext/ 120194833/PDFSTART >. Accessed: Feb. 18, 2010. doi: 10.1046/j.1463-5224.1998.00006.x.

KLOSTERMAN, E. et al. Immunohistochemical properties of ocular adenomas, adenocarcinomas and medulloepitheliomas. Veterinary Ophthalmology, v.9, n.6, p.387-394, 2006. Available from: <http://www3.interscience.wiley.com/cgi-bin/ fulltext/118599226/PDFSTART>. Accessed: Feb. 18, 2010. doi: $10.1111 / \mathrm{j} .1463-5224.2006 .00478 . x$.

KOMAROMY, A.M. et al. Primary adenocarcinoma of the gland of the nictitating membrane in a cat. Journal of the American Animal Hospital Association, v.33, n.4, p.333-336, 1997. Available from: <http://www.jaaha.org/cgi/ content/abstract/33/4/333>. Accessed: Feb. 18, 2010.

KREHBIEL, J.D.; LANGHAM, R.F. Eyelid neoplasms in dogs. American Journal of Veterinary Research, v.36, n.1, p.115-119, 1975.

LIAPIS, I.K.; GENOVESE, L. Hemangiosarcoma of the third eyelid in a dog. Veterinary Ophthalmology, v.7, p.279-282, 2004. Available from: <http://www3.interscience.wiley.com/cgibin/fulltext/118811887/PDFSTART>. Accessed: Feb. 18, 2010. doi: $10.1111 / \mathrm{j} .1463-5224.2004 .04031 . x$.

LORIMIER, L.P. Primary orbital melanoma without ocular involvement in a Balinese cat. Canadian Veterinary Journal, v.47, n.3, p.225-228, 2006. Available from: <http:// www.ncbi.nlm.nih.gov/pmc/articles/PMC $1371049 /$ pdf/ cvj47pg225.pdf>. Accessed: Feb. 18, 2010.

MATTON, J.S.; NYLAND, T.G. Small animal ultrasound. 2.ed. Philadelphia; Saunders, 2002. 461p.
MILLER, P.E.; DUBIELZIG, R. Ocular tumors. In: Withrow, S.A.; VAIL, D.M. Small animal clinical oncology. 4.ed. St. Louis: Saunders, 2005 . Chap.30. p.686-697.

MONTIANI-FERREIRA, F. et al. Corneal squamous cell carcinoma in a dog: a case report. Veterinary Ophthalmology, v.11, n.4, p.269-272, 2008. Available from: <http://www3.interscience.wiley.com/cgi-bin/fulltext/ 120751721/PDFSTART>. Accessed: Feb. 18, 2010. doi: 10.1111/j.1463-5224.2008.00622.x.

MULTARI, D. et al. Hemangiosarcoma of the third eyelid in a cat. Veterinary Ophthalmology, v.5, p.273-276, 2002. Available from: http://www3.interscience.wiley.com/cgi-bin/ fulltext/118927843/PDFSTART. Accessed: Feb. 18, 2010. doi: 10.1046/j.1463-5224.2002.00254.x.

PATNAIK, A.K.; MOONEY, S. Feline melanoma: a comparative study of ocular, oral and dermal neoplasms. Veterinary Pathology, v.25, n.2, p.105-112, 1988.

PEREIRA, J.S. et al. Immunohistochemical characterization of intraocular metastasis of a canine transmissible venereal tumor. Veterinary Ophthalmolology, v.3, n.1, p.43-47, 2000. Available from: <http://www3.interscience.wiley.com/ cgi-bin/fulltext/119051285/PDFSTART >. Accessed: Feb. 18, 2010. doi: 10.1111/j.1463-5224.2000.00097.x.

PIRIE, C.G. et al. Canine conjunctival hemangioma and hemangiosarcoma: a retrospective evaluation of 108 cases (1989-2004). Veterinary Ophthalmology, v.9, p.215-226, 2006. Available from: <http://www3.interscience.wiley.com/ cgi-bin/fulltext/118599202/PDFSTART>. Accessed: Feb. 18, 2010. doi: $10.1111 /$ j.1463-5224.2006.00471.x.

RODRIGUES Jr, E.F. et al. Metastatic intraocular chondrosarcoma in a dog. Veterinary Ophthalmology, v.12, n.4, p.254-258, 2009. Available from <http://www3.interscience.wiley.com/journal/ 122499190/abstract?CRETRY $=1 \&$ SRETRY $=0>$. Accessed: Feb. 18, 2010. doi: 10.1111/j.1463-5224.2009.00703.x.

WILLIS, A.M.; WILKIE, D. Ocular oncology. Clinical techniques in small animal practice, v.16, n.1, p.77-85, 2001.

WOOG, J. et al. Osteossarcoma in a phthisical feline eye. Veterinary Pathology, v.20, n.2, p.209-214, 1983. 